\title{
TAX TREATY OVERRIDE IN SLOVAKIA - DIGITAL PLATFORM PERMANENT ESTABLISHMENT
}

\author{
Tomáš Cibul'a, Matej Kačaljak \\ Comenius University in Bratislava, Faculty of Law
}

\begin{abstract}
The article analyses the new "digital platform permanent establishment" concept as a legal fiction establishing a fixed place even in situations where there is no actual fixed place. The authors conclude that in the Slovak legal environment this concept is not capable of (i) being applied through the interpretation of the tax treaty, or (ii) overriding the tax treaty. Its practical implications in a tax treaty situation must be analysed on a case-by-case basis. The ineffectiveness of the concept mainly stems from the fact that Slovak statutory rules are generally incapable of overriding tax treaties. It may still be applicable in a dualist legal environment, but international law treaty override implications would still remain valid.
\end{abstract}

Key words: corporate income tax, treaty override, permanent establishment, digital services, digital platform

\section{INTRODUCTION}

The topic of this article is the relatively new initiative of the Slovak Republic aiming at the taxation of digital services through a legal fiction establishing a permanent establishment in the territory of the Slovak Republic even without the actual physical presence of the enterprise. The doctrinal problem lies in the co-existence of a local rule with income attribution rules in the Double Tax Treaties to which the Slovak Republic is a party. The article builds on the previous doctrinal work dealing with treaty overrides ${ }^{1}$ and takes into account the implications of the Multilateral Convention to Implement Tax Treaty Related Measures to Prevent Base Erosion and Profit Shifting ("MLI"). ${ }^{2}$ The article is topical from the perspective of testing new approaches to the taxation of the digital economy. ${ }^{3}$

\section{THE DIGITAL PLATFORM PERMANENT ESTABLISHMENT CONCEPT}

On 1 January 2018, the Slovak Republic introduced the "digital platform" concept to the Income $\operatorname{Tax} \operatorname{Act}^{4}$ (“ITA").

1 For an up to date list of literature on the topic, see MIKIC, M. Selective Bibliography on Tax Treaty Override. In European taxation, 53(9). From Slovak perspective, particularly in the view of implications of Slovak GAAR see also KORONCZIOVÁ, A. KAČALJAK, M. Gaar As Tax Treaty Override-Slovak Perspective. In DANUBE: Law and Economics Review, 8.3 (2017), pp. 139 - 155.

2 See further on the topic of MLI e.g. OWENS, J. BEPS Implementation: The Role of a Multilateral Instrument. In Int'l Tax Rev., 26 (2015), p. 18. and BRAVO, N. The Multilateral Tax Instrument and Its Relationship with Tax Treaties. In World tax journal, 8.3 (2016).

3 See further OLBERT, M., SPENGEL, Ch. International taxation in the digital economy: challenge accepted? In World tax journal, 9.1 (2017).

4 Act No. 595/2003 Coll. on Income Tax as amended 


\section{Definition of Digital Platform}

The Digital Platform is now defined in Section 2(ag) of the ITA a "a hardware or software platform required for the creation of applications and their management".

In the Explanatory Notes to the draft amendment of the ITA ("Explanatory Notes") the digital platform is further described as an "innovative technological business model that allows the exchange of information between several groups of users, especially between end-users and holders of a movable or immovable property or service providers. It is available to other users and shares data with thirdparty developers. It is easy to use without the need of training and represents an innovative business model".

Therefore, though the definition in the Working Draft is not ideal and may result in uncertainty and controversies in the future, taking into account its wording and explanations in the Explanatory Notes, it seems clear that it should cover businesses that intermediate accommodation services, such as Booking, AirBNB and Uber.

Nevertheless, it is not the definition itself that may cause controversy, but the concept of a "digital platform permanent establishment" which is structured around this definition.

\section{Digital Platform Permanent Establishment}

As of 1 January 2018, the following wording was included in the ITA “The performance of activities with a permanent place in the Slovak Republic is considered also the repeated intermediation of transport and accommodation services, even via a digital platform."

Thus a fiction of a permanent establishment under Slovak law for digital platforms was created, even if there is no fixed place located in the Slovak Republic.

Pursuant to the Explanatory Notes, "[t]he aim of the expansion of the permanent establishment definition is to introduce a legal fiction because the current wording of the [ITA] does not reflect modern business models of recent years, where activities are provided without the physical presence of the entrepreneur in the relevant territory. Nowadays, the virtual presence of an entrepreneur is sufficient enough for the performance of activities in another country. This leads to discrimination between entrepreneurs. Entrepreneurs doing business in the Slovak Republic through digital platforms thus earn Slovak-sourced income without taxing it in the Slovak Republic."

Accordingly, such income of this "digital platform permanent establishment" is deemed a Slovak sourced income and is subject to income tax in Slovakia.

Finally, an already existing withholding tax obligation was amended with effect from 1 January 2018 so that Slovak sourced income attributable to a permanent establishment of a non-Slovak tax resident in Slovakia is not subject to withholding tax only if such permanent establishment is registered for income tax purposes in Slovakia. Previously there was no registration requirement and the existence of the permanent establishment was sufficient.

\footnotetext{
5 It is interesting to note that the original wording in the working draft of the bill introducing the digital platform concept "digital platform" as "a hardware and software platform required for the creation of applications and their management". It is difficult to see the reason of a change of the definition from "hardware and software platform" to "hardware or software platform", as pure hardware platform without software running on it can hardly provide any services. In other words, the mention of "hardware platform" in the definition seems to be obsolete and irrelevant - it is software that allows provision of intermediation services, not the hardware on which the software is running.
} 


\section{CRITICAL ASPECTS OF THE DIGITAL PLATFORM PERMANENT ESTABLISHMENT CONCEPT}

The concept of a "digital platform permanent establishment" clearly goes beyond the current concept of a permanent establishment under both the OECD Model Tax Convention and UN Model Tax Convention and treaties based on these models (jointly the "Model Tax Conventions"), which is based on the existence of a fixed place. Therefore, it raises several issues with respect to potential treaty overrides, which will be discussed in detail below. In particular:

(i) if the concept could be in line with the renvoi method anticipated in Art. 3(2) of the OECD Model Tax Convention and Art. 3(2) of the UN Model Tax Convention and all the tax treaties based on these models or containing similar language; if not

(ii) if the concept is capable of overriding the tax treaties to which Slovak Republic is a party; and, if not

(iii) what are the practical legal implications that might be reasonably anticipated from the concept.

\section{Compatibility with the renvoi method}

The wording of the digital platform permanent establishment concept implies that the Slovak legislator was under the impression that the term "fixed place" may be regarded as an undefined term and, as such, may be subject to interpretation through the renvoi method, i.e., through reference to a rule of domestic law.

Firstly, to allow for the application of the renvoi method, it must first be concluded that the term "fixed place" is in fact undefined.

The literature ${ }^{6}$ concludes that the term "permanent establishment" should be used in line with the autonomous interpretation method, i.e., the "interpretive activity is carried out entirely within the treaty system and covers terms and concepts that are sufficiently defined by the treaties". Applying the argumentum a maiori ad minus, if the entire permanent establishment term is to be interpreted within the treaty system, this implies that no partial term forming the whole of the permanent establishment concept may be interpreted with reference to domestic law (as the entire term "permanent establishment" would then clearly not be autonomous).

Secondly, the application of the renvoi method is limited to situations where "the context does not require an alternative interpretation and the competent authorities do not agree on a different meaning [pursuant to a mutual agreement procedure]" "Though there are various approaches to what comprises the "context" of the treaty ${ }^{8}$, some relevance is given to the commentaries to Model Tax Conventions existing at the time of entering into the relevant tax treaty and, these rather unequivocally refer to the term "fixed place" in its material meaning without regard to any diverging domestic definitions."

6 GARBARINO, C. Judicial Interpretation of Tax Treaties: The Use of the OECD Commentary. Cheltenham UK: Edward Elgar Publishing, 2016, p. 21 (I.63).

7 Commentary to Article 3(2) of the OECD Model Tax Convention, OECD. (2015) Model Tax Convention on Income and on Capital 2014 (Full Version). Paris : OECD Publishing, p. 102.

8 GARBARINO, C. Judicial Interpretation of Tax Treaties: The Use of the OECD Commentary. Cheltenham UK: Edward Elgar Publishing, 2016, p. 22 (I.66).

9 Commentary to Article 5 of the OECD Model Tax Convention, OECD. (2015) Model Tax Convention on Income and on Capital 2014 (Full Version). Paris : OECD Publishing, p. 116. 
Finally, even if we conceded ${ }^{10}$ that the term "fixed place" is capable of being interpreted through the renvoi method, one must bear in mind the basic interpretation principles within public international law, in particular, the rules of the Vienna Convention $(1969)^{11}$, where a "treaty" is defined as "an international agreement concluded between States in written form and governed by international law, whether embodied in a single instrument or in two or more related instruments and whatever its particular designation". With the absence of any derogation with respect to tax treaties, the Vienna Convention (1696) should apply to all tax treaties entered into between its members after its entry into force with regard to such states. " ${ }^{12}$ "As regards tax treaties between states that are not parties to the Convention or tax treaties that were concluded prior to the entry into force of the Convention [its] principles may be applicable as [it] codifies the rules of customary international law." 13

In particular, Articles 26 and 27 stand out in this respect. Article 26 embodies the pacta sunt servanda principle and reads: "Every treaty in force is binding upon the parties to it and must be performed by them in good faith." Further, Article 27 reads that "A party may not invoke the provisions of its internal law as justification for its failure to perform a treaty."

In this perspective it must be concluded that only such reference to domestic law which adhered to the pacta sunt servanda principle ${ }^{14}$ may be acceptable in the renvoi interpretation method.

The interpretation of the term "fixed place" in line with the "digital platform permanent establishment" would inevitably shift income attribution in favour of the Slovak Republic. A fortiori one may think of other domestic concepts that could thus be implanted in the permanent establishment definition by (pseudo) defining the term "fixed place". Ad absurdum one could enact a rule stating that a "fixed place exists in every case even if there is no fixed place". 15

Thus, it must be concluded that the Slovak "digital platform permanent establishment" concept is not in line with the renvoi method and, thus, is incapable of being applied to tax treaty situations through interpretation.

\section{Aspects}

The MLI modifies the application of existing bilateral double taxation treaties in several aspects agreed between its signatories. On 7 June 2017, the MLI was signed by 67 countries (including the Slovak Republic) covering 68 jurisdictions. Each jurisdiction was required to provide a list of bilateral treaties to be covered and details on how they would be modified by the MLI ("MLI Position").

Pursuant to the Slovak MLI Positions, there are significant changes to the tax treaties. The following changes to the tax treaties are relevant from the perspective of digital platforms:

a) Prevention of treaty abuse;

b) Artificial avoidance of permanent establishment status through commissionaire arrangements and similar strategies (Article 12 of the MLI); and

10 Purely hypothetically and for the sake of expanding our argumentation.

11 Vienna Convention on the law of treaties concluded at Vienna on 23 May 1969. The Slovak Republic is bound by the Vienna Convention as a successor state of Czechoslovakia, upon which it was binding from 28 August 1987.

12 Article 4 of the Vienna Convention (1969).

13 GERZOVA, L., POPA, O. Compatibility of Domestic Anti-Avoidance Measures with Tax Treaties. In European taxation, 53, 9 (2013). See also MAISTO, G. (ed.). Tax treaties and domestic law. Amsterdam : IBFD, 2006

14 Similar conclusion was reached also by the Court of Justice of the European Union in its judgements from 12 September 2017, C-648/15.

15 It is worth noting that is exactly what the Slovak "digital platform permanent establishment" concept does. 
c) Artificial avoidance of permanent establishment status through specific activity exemptions (option A under Article 13 of the MLI).

\section{Prevention of Treaty Abuse}

As follows from the Slovak MLI Position, there is an intention to modify the tax treaties by including the following:

a) a new text in the preamble declaring the intent to eliminate double taxation without creating opportunities for non-taxation or tax avoidance (Article 6 of the MLI); and

b) the principal purpose test ("PPT"), being a general anti-abuse rule and denying treaty benefits in cases where one of the principal purposes of an arrangement was to obtain a treaty benefit (Article 7 of the MLI).

Theoretically, with regard to the MLI Position, Slovak tax authorities might possibly argue that a narrower definition of a permanent establishment under the DTT would not apply as a result of the PPT and they would instead apply the definition in the ITA, effectively denying treaty protection. Overall, however, we believe that this argumentation line stems from the generality of the wording of the PPT and the absence of specific guidance, but in principle we think it may be very difficult to sustain such argumentation.

\section{Provisions on the artificial avoidance of permanent establishment status through commissionaire and similar arrangements - Article 12 of the MLI}

By using commissionaire agreements and similar strategies, and under certain circumstances, the current rules allow enterprises from one state to sell their products in another state through local agents without technically having a permanent establishment in that other state. Commissionaire agreements and similar agreements rely on the exemptions in Article 5(5) and (6) of the Model Tax Conventions, under which no permanent establishment should arise in commissionaire structures.

The main purpose of the changes made by Article 12 of the MLI is to limit the use of the exemption in cases where the activities of an intermediary from the second state regularly result (and the intermediary plays a principal role) in the conclusion of contracts to be performed by an enterprise from the first state. In such case, the foreign enterprise should be deemed to have a permanent establishment in the second state, unless the intermediary is an independent agent.

However, in the context of the digital economy, the involvement of a local dependent agent is rarely needed and the "digital platform" definition seemingly anticipates that no such presence will exist in the Slovak territory. Therefore, these changes should be without relevance to the "digital platform permanent establishment" concept.

\section{Provisions on the artificial avoidance of permanent establishment status through specific activity exemptions - Article 13 of the MLI}

The activities listed in Article 5(4) of the OECD Model Convention were historically implied to be preparatory or auxiliary in nature, and as such, they did not generally give rise to permanent 
establishments, i.e., these activities were an exemption from the general rule of when a permanent establishment is created.

However, under some circumstances such activities may form core business activities of an enterprise. Therefore, the exemption to these activities should only apply if these activities are indeed of a preparatory or auxiliary nature (rather than being automatically so classified).

The changes made by Article 13 of the MLI limit the activities listed in Article 5(3) of the tax treaties based on the Model Tax Conventions (or in similar provisions of treaties not based on these models) only to such an extent that indeed they are of a preparatory or auxiliary nature.

In any case, the above should in principle only be considered if there is a fixed place.

Thus, this change should also be without relevance to the "digital platform permanent establishment" concept.

\section{Tax treaty override}

Having concluded that the "digital platform permanent establishment" concept may not be applied through an interpretation of a tax treaty, the question of whether it is capable of overriding the respective tax treaty needs to be analysed.

In general "treaty override by way of application of domestic legislation or interpretation of such legislation leading to failure to perform a treaty, in principle, constitutes a breach of states' obligations under international law, regardless of the permissibility of such an override under domestic law." ${ }^{16}$ Nevertheless, the set of available remedies under international law is relatively limited (the suspension or termination of the tax treaty being one of them $)^{17}$ and for various reasons tax treaty overrides still occur.

The approach of states to treaty overrides varies greatly even within the OECD member states. ${ }^{18}$ The interaction between domestic law and international law depends on the constitutional order of the particular states. ${ }^{19}$ While in states adhering to the dualistic approach it is more likely that a treaty override would be found in line with their legal principles, ${ }^{20}$ in states applying the monistic approach with a clearly defined precedence of international treaties before local law provisions, any provisions of local laws or judicial practice would be found unconstitutional per se. ${ }^{21}$

As an example, the United States of America overrides its treaties based on the lex posterior derogat legi priori principle embedded in legislation and judicial practice. ${ }^{22}$ Similarly, relatively recently the Federal Court of Germany held that the treaty override is constitutional. ${ }^{23}$

16 GERZOVA, L., POPA, O. Compatibility of Domestic Anti-Avoidance Measures with Tax Treaties. In European taxation, $53,9(2013)$.

17 GERZOVA, L., POPA, O. Compatibility of Domestic Anti-Avoidance Measures with Tax Treaties. In European taxation, 53, 92013). See also MAISTO, G. (ed.). Tax treaties and domestic law. Amsterdam : IBFD, 2006.

18 For illustration consult the observations of states to the OECD Commentary to Article 1 of the OECD Model Tax Convention OECD (2015).

19 SACHDEVA, S. Tax Treaty Overrides: A Comparative Study of the Monist and the Dualist Approaches. In Intertax, 41, 4 (2013), pp. 180 - 207.

20 International law consequences are not taken into account for this part of analysis.

21 For discussion of monism and dualism see further AUST, A. Modern treaty law and practice. Cambridge : Cambridge University Press, 2007, p. 159 et seq.

22 GERZOVA, L., POPA, O. Compatibility of Domestic Anti-Avoidance Measures with Tax Treaties. In European taxation, 53, 9 (2013). See also MAISTO, G. (ed.). Tax treaties and domestic law. Amsterdam : IBFD, 2006.

23 CLOER, A., HAGEMANN, T. Constitutionality of Treaty Override. In European taxation, 56, 7 (2016). 
On the other hand, in states where the precedence of international treaties ${ }^{24}$ is clearly stated in their constitutions, neither the legislator nor the courts have the power to ignore (or reverse) this order even if the circumstances might justify such approach.

In Slovakia the theoretical difference may stem from the fact that dualistic theory prevailed within the territory of the Slovak Republic until the amendment of Act No. 460/1992 Coll. - the Constitution of the Slovak Republic in 2001. This amendment brought the change in favour of the monistic theory with the primacy of the international law.

The theoretical possibility of a tax treaty override would then depend on whether the tax treaty was ratified and promulgated:

(A) before 1 July 2001 (where a soft dualist approach would apply and their precedence over national law would stem from local law provisions); or

(B) on or after 1 July 2001 (where a monist approach would apply and their precedence over national law would stem directly from the Constitution). ${ }^{25}$

It seems clear that the new "digital platform permanent establishment" concept would be incapable of overriding tax treaties referred to in (B) above.

With respect to treaties referred to in (A), it would be theoretically possible to override these by a local law rule. However, it would need to be settled that such local law rule derogates the general rule in Section 1(2) of the ITA, which stipulates that an international treaty "has precedence over this act". In the absence of a clear expression stating that such precedence would not apply in relation to (e.g.) the permanent establishment definition, we would conclude that the new "digital platform permanent establishment" concept is not capable of overriding this general tax treaty precedence rule (and, thus, the tax treaty itself).

We are of the view that the rule setting precedence of a tax treaty is a special rule to all the remaining rules in the ITA and, thus, should always prevail (lex posterior derogat legi priori approach, as inferior approach, is thus not applicable).

Thus, it must be concluded that the "digital platform permanent establishment" concept is not capable of overriding tax treaties.

\section{Practical implications}

Having concluded that the "digital platform permanent establishment" concept is not capable of (i) being applied through interpretation of a tax treaty, or (ii) overriding the tax treaty, its practical implications in a tax treaty situation must be analysed.

These would differ depending on whether the concept and corresponding obligations result in the assessment of tax or in another obligation / circumstance.

With respect to the potential assessment of tax it seems clear that no tax could be assessed with respect to incomes of a non-Slovak tax resident attributable solely to the digital platform. In this respect we find it relevant to note that Article 5 of the Model Tax Conventions might not be regarded as "self-executing", i.e., the definition of permanent establishment would likely not be implemented

24 For example, Czech Republic and Slovak Republic, Greece, Spain, Croatia. See further MAISTO, G. (ed.). Tax treaties and domestic law. Amsterdam : IBFD, 2006.

25 See further KORONCZIOVÁ, A., KAČALJAK, M. Gaar As Tax Treaty Override-Slovak Perspective. In DANUBE: Law and Economics Review, 8.3 (2017), pp. 139 - 155. 
into Slovak law and applied as if it were a local law rule. Invariably, it is essential in the application of Article 7, which is self-executing and clearly states that "profits of an enterprise of a Contracting State shall be taxable only in that State unless the enterprise carries on business in the other Contracting State through a permanent establishment situated therein". ${ }^{26}$

Thus, a "digital platform permanent establishment" might come into existence under Slovak law (and the Slovak tax authorities would register it for income tax purposes on an ex offo basis), but still under the respective treaty such non-Slovak tax resident could rely on the protection of Article 7 and no tax could be levied on the profits of such digital platform in Slovakia.

Likewise, although Slovak law imposes a withholding obligation with respect to profits of an unregistered permanent establishment, it would still first need to be concluded that such profits were attributable to this permanent establishment and may theoretically form a Slovak sourced income. With respect to the above, clearly not. ${ }^{27}$

In practice, it would then be without practical implications if the "digital platform permanent establishment" were registered for tax in Slovakia.

Thus, the new concept seems to only result in additional administrative obligations of Slovak tax offices, which would have to perform searches and register "digital platform permanent establishments", but clearly without any further potential for generating tax income.

\section{CONCLUSION}

Since the "digital platform permanent establishment" concept in the Slovak legal environment is not capable of (i) being applied through interpretation of a tax treaty, or (ii) overriding the tax treaty, its practical implications in a tax treaty situation must be analysed.

In practice it would only result in additional administrative obligations for the Slovak tax offices, which would have to perform searches and register "digital platform permanent establishments", but without any potential for generating tax income.

As such, the concept would very likely become redundant and removed from the ITA.

Nevertheless, certain credit must be given to Slovak legislators for identifying the problem and their pioneering efforts at addressing it.

Finally, the ineffectiveness of "digital platform permanent establishment" concept mainly stems from the fact, that Slovak statutory rules are generally incapable of overriding tax treaties. This concept might still be applicable in a dualist environment, but the international law treaty override implications would remain valid.

\section{Acknowledgements}

Supported by the Slovak Research and Development Agency (APVV) Grant APVV-16-0499.

26 Assuming there are no specific provisions in the respective tax treaty expressly dealing with digital economy.

27 In this perspective it needs to be reminded that a tax at source (through e.g. withholding tax) is "a particular taxation technique, rather than a type of tax, intended essentially to secure (minimum) taxation ", see e.g. Opinion of Advocate General Kokott delivered on 1 March 2018, Case C-115/16, section 85. 


\section{Bibliography:}

AUST, A. Modern treaty law and practice. Cambridge : Cambridge University Press..., p. 159 et seq.

BRAVO, N. The Multilateral Tax Instrument and Its Relationship with Tax Treaties. In World tax journal, 8.3 (2016).

CLOER, A., HAGEMANN, T. Constitutionality of Treaty Override. European taxation, 56, 7 (2016).

GARBARINO, C. Judicial Interpretation of Tax Treaties: The Use of the OECD Commentary. Cheltenham UK : Edward Elgar Publishing, 2016.

GERZOVA, L., POPA, O. Compatibility of Domestic Anti-Avoidance Measures with Tax Treaties. In European taxation, 53, 9 (2013).

MAISTO, G. (ed.). Tax treaties and domestic law. Amsterdam : IBFD, 2006.

MIKIC, M. Selective Bibliography on Tax Treaty Override. In European taxation, 53, 9 (2013). KORONCZIOVÁ, A., KAČALJAK, M. Gaar As Tax Treaty Override-Slovak Perspective. In Danube: Law and Economics Review, 8.3 (2017), pp. 139 - 155.

OECD. Model Tax Convention on Income and on Capital 2014 (Full Version). Paris : OECD Publishing, 2014.

OLBERT, M., SPENGEL, Ch. International taxation in the digital economy: challenge accepted? In World tax journal, 9.1 (2017).

OWENS, J. BEPS Implementation: The Role of a Multilateral Instrument. In Int'1 Tax Rev., 26 (2015), p. 18.

Vienna Convention on the law of treaties concluded at Vienna on 23 May 1969.

SACHDEVA, S. Tax Treaty Overrides: A Comparative Study of the Monist and the Dualist Approaches. In Intertax, 41, 4 (2013), pp. $180-207$.

\section{Contact information:}

JUDr. Ing. Tomáš Cibula, LL.M.

tcibula@whitecase.com

Comenius University in Bratislava, Faculty of Law

Šafárikovo nám. Č. 6

81000 Bratislava

Slovak Republic

The author is a senior associate at White \& Case. However, this article and the ideas stated therein represent his personal views and not those of White \& Case.

doc. JUDr. Ing. Matej Kačaljak, PhD.

matej.kacaljak@flaw.uniba.sk

Comenius University in Bratislava, Faculty of Law

Šafárikovo nám. Č. 6

81000 Bratislava

Slovak Republic 